\title{
The potential role of omega-3 fatty acids supplements in increasing athletic performance
}

\author{
Șerban GLIGOR¹, Răzvan GLIGOR ${ }^{2}$
}

\begin{abstract}
Polyunsaturated omega- 3 and omega- 6 fatty acids are essential fatty acids that cannot be produced by the body itself and therefore must be provided through nutrition. Omega- 6 and particularly omega- 3 fatty acids have important roles in the organism, contributing to the maintenance and promotion of health. The optimal proportion of omega-6/omega-3 fatty acids is $2: 1$, or even better 1:1. They are involved in normal growth and development, play a role in the prevention of coronary and cardiovascular diseases, of diabetes mellitus, of arterial hypertension, arthritis and cancer. Omega- 3 fatty acids mainly have an anti-inflammatory effect, but also act as hypolipidemic and antithrombotic agents. A potential role of omega- 3 fatty acids is that of increasing physical performance. Their role in the physical activity refers on one side to the global health of athletes and on the other side to their anti-inflammatory effect, as high intensity physical exercise induces increased free-radical production and microtraumas, with the induction of an inflammatory status. The anti-inflammatory effect of these fatty acids manifests through an increased production of endogenous antioxidant enzymes, through decreasing the production of prostaglandins metabolites, decreasing the production of leukotriene $\mathrm{B}_{4}$, etc. They are also effective on reducing muscle pain post eccentric exercise and on decreasing the severity of bronchoconstriction induced by exercise, as well as improving pulmonary function variables. In conclusion it seems that supplementing diets with omega-3 fatty acids, apart from having benefic effects on health and on the prevention and management of certain affections, proves to be a beneficial for physical activity and athletic performance.
\end{abstract}

Key words: omega-3 fatty acids, athletic performance, anti-inflammatory effect, pain.

\section{Rezumat}

Acizii grași polinesaturați omega-3 și omega- 6 sunt acizi grași esențiali care nu se pot produce în organism și de aceea trebuie asigurați prin alimentație. Acizii grași omega- 6 și mai ales omega-3 au roluri foarte importante în organism, contribuind la menținerea și promovarea sănătății. Raportul optim acizi grași omega-6/omega-3 este de 2:1, sau mai bine 1:1. Ei sunt implicați în creșterea și dezvoltarea normală și au rol în prevenția bolii cardiace coronare, a diabetului zaharat, a hipertensiunii arteriale, artritei și cancerului. Acizii grași omega-3 au în principal rol antiinflamator, dar și hipolipidemic și antitrombotic. Un rol potențial al acizilor grași omega-3 este acela de îmbunătățire a performanței sportive. Rolul acestor acizi în activitatea fizică se referă pe de-o parte la sănătatea globală a atleților și pe de altă parte se datorează efectului antiinflamator, exercițiul fizic de intensitate mare determinând creșterea producerii de radicali liberi de oxigen și microtraumatisme, cu apariția unui status inflamator. Efectul antiinflamator al acestor acizi grași se realizează prin creșterea producerii enzimelor endogene antioxidante, scăderea producției de metaboliți ai prostaglandinelor, scăderea formării leucotrienelor $\mathrm{B}_{4}$ etc. Ei au și un efect de reducere a durerii musculare post exerciții excentrice și de reducere a severității bronhoconstricției induse de exerciții, precum și de îmbunătățire a unor variabile pulmonare. În concluzie, se pare că suplimentarea cu acizi grași omega-3 a dietelor, pe lângă efectele benefice asupra sănătății și de prevenire și management a unor afecțiuni, se dovedește a fi un element benefic pentru activitatea fizică și performanța sportivă.

Cuvinte cheie: acizi grași omega-3, sănătate, performanță sportivă, efect antiinflamator, durere.

\footnotetext{
${ }^{1}$ Associate Professor MD, PhD, Faculty of Physical Education and Sport, West University of Timisoara, e-mail: serban.gligor@e-uvt.ro

${ }^{2}$ Lecturer MD, PhD, Faculty of Medicine, "Vasile Goldiș" Western University of Arad
} 


\section{Introduction}

As early as 1963 , Hansen A. et al. have proven that maintaining a good health status in individuals depends on the input of certain polyunsaturated fatty acids in the nutrition. [1,2] The nutrition includes lipids, that based on the predominant fatty acid, are classified as saturated and unsaturated fatty acids. [3,4] Unsaturated fatty acids are also classified as monounsaturated and polyunsaturated. When containing two or more double bonds are called polyunsaturated (PUFA). [5,6] From the polyunsaturated fatty acids, the most important in the nutrition are omega 3 and omega 6 , that get their name from the location of the last double bond in regard to the methyl termination of the molecule. $[6,7]$ They are essential fatty acids because they cannot be synthetized in the body and therefore have to be provided through diet. $[3,4,6]$

The main omega-3 fatty acids are the alphalinolenic acid (ALA), the Eicosapentaenoic acid (EPA) and the Docosahexaenoic acid (DHA) that are present in fatty fish (such as salmon, white tuna, mackerel, herring and sardines) and in fish oil (EPA and DHA), in canola seeds, soybean oil, walnuts, ground flaxseed or flax seed. The best source for omega- 6 fatty acids, respectively the linoleic acid (LA) are vegetable oils (e.g. corn, sunflower, safflower and soybean oil), nuts, whole bread and chicken meat. [3]

The daily intake of omega- 3 fatty acids varies from country to country. Hence, in European countries, the omega-3 fatty acids intake varies between 0.1 and $0.5 \mathrm{~g} /$ day, while in Japan the intake is up to 2 g/day. Furthermore, the nutritional recommendation given by international health agencies varies as well. "The American Heart Association" (AHA) has recommended that healthy adults should eat fish at least twice a week in order to insure the necessary omega- 3 fatty acids intake of approximately 1 g. [2,3] "World Health Organization" (WHO) recommends a daily intake of 0.3-0.5 g/day, and the "International Society for the Study of Fatty Acids" (ISSFAL) recommendation is of 500 g/day. [2] The "US Food and Drug Administration" (FDA) has designated as safe a dose of $\leq 3000 \mathrm{mg} /$ day of omega-3 fatty acids (DHA+EPA). [8]

In the case of omega- 6 fatty acids, AHA recommended in 2009 that at least 5\% and up to
$10 \%$ of the calories has to come from omega- 6 fatty acids, in association with other AHA recommendations referring to life-style and diet. $[2,3]$ According to epidemiologic studies eating fish is correlated with a decrease in morbidity and mortality rates through cardiovascular diseases, with the condition that omega- 3 fatty acids are found in the body in adequate proportions. [9,10] According to Simopoulos A., the optimal proportion of omega-3/omega- 6 is from $3: 1$ to $5: 1$. $[9,11]$

In the last decades, major nutritional changes related to nutrition quality have taken place, with an increased consumption level for fatty acids that now represent $28-42 \%$ from the daily energetic intake at a European level. [6,12] Traditionally, for maintaining general health throughout the population, the proportion of omega-3/omega- 6 fatty acids was 1:1. Nowadays, a decreased consumption of fish, the main source for omega-3 fatty acids, has been observed, together with an increased consumption of animal source foods (such as hen and captivity fish) that contain an increased percentage of omega- 6 fatty acids [11], as well as increased consumption of vegetable oils rich in linoleic acid (LA). $[6,13]$ The result of these diet changes is the nowadays nutrition model that is characterized by an increased intake of saturated fats, omega- 6 fatty acids and trans-fatty acids, as well as a decreased intake of omega- 3 fatty acids. $[6,14]$

An optimal proportion of the omega-3/omega- 6 fatty acids is very important for the maintenance of health, with an optimal proportion of $1: 1$ to $4: 1$ [6] Apposite to the nutritional changes in the modern diet this proportion has now risen from 10:1 up to $20: 1$. [6,12] It is thought that for the prevention and treatment of cardiovascular diseases the adequate proportion between these fatty acids need to be $4: 1$, this being associated with a $70 \%$ mortality reduction. [6,14] According to some authors, in cancer, the ideal omega-3/omega-6 proportion would be $1: 1$ or $2: 1[2,15]$, and in the case of asthma a benefic proportion would be $5: 1 .[2,16]$

Garcia-Rios et al. state that the individualized treatment with both type of acids, that insure an optimal daily intake, seems to be more rational than analyzing their proportions. [2,17]

An optimal diet model that would reduce complications of cardiovascular diseases, as well as 
mortality rates, needs to include a low intake of saturated fatty acids, as well as omega- 6 fatty acids, and a moderate intake of omega-3 fatty acids. [18] This nutrition profile is very similar to the traditional Mediterranean diet, which is rich inmonounsaturated fats from plants and poor in industrial trans-fatty acids. [19,20] It includes a complex different lipids that influence one another, mainly conjugated and unconjugated trans fatty acids, saturated short-chain, medium-chain and long-chain fatty acids, and a wide range of monounsaturated fatty acids, as well as polyunsaturated fatty acids.[19,20]

Polyunsaturated fatty acids (PUFA) play an important role building all cellular membranes; they have high affinity for phospholipids and can replace the linoleic and arachidonic acid in certain phospholipids (phosphatidylcholine). [4]

It has been proven that fatty acids, regardless from their source, either from membranous phospholipids or from dietary input, are important cellular signaling molecules. They can act as secondary messenger and can rapidly modify transcription for specific genes. [21,22]

Depending on the location of the last double bond, they regulate a variety of biological functions, from blood pressure, to normal development and functionality of the brain and of the nervous system. [6,7] Moreover, PUFA are precursors for eicosanoids that are potent lipid mediators of signaling molecules and that play important roles in the regulation of immunity and inflammation. Eicosanoids can be generated from long-chain PUFA that are highly unsaturated, both from the omega- 6 series (arachidonic acid) and from the omega-3 series (EPA and DHA). [5,6] They are biologically active and include prostaglandins (PG), thromboxane, leukotriene and eicosatetraenoic acid (HETE), that are all involved in a variety of pathologies such as inflammation and cancer. $[6,23]$ Under the action of cyclooxygenases (COX) and lipoxygenases (LOX), arachidonic acid can be converted to $\mathrm{PG}$, thromboxane and leukotriene. $[6,24]$

Linoleic acid (from omega-6), alpha-linolenic acid (from omega-3) as well as their long-chain derivate are important components of the cellular membranes of plants and animals. [22] If the diet includes high quantities of omega- 6 fatty acids, the eicosanoids metabolism products formed from arachidonic acid will reach higher quantities than those form the omega-3 fatty acids (EPA respectively) and will lead to the formation of thrombi and atheroma plaques, to inflammatory dysfunctions, allergies and cellular proliferation. $[6,22,25]$ If fish and fish oil containing EPA and DHA are included in the diet, these acids will partially replace omega-6 fatty acids, especially the arachidonic acid from cell membranes of thrombocytes, erythrocytes, neutrophils, monocytes and hepatocytes, where it is usually found in higher degree. [6,11,26] Generally speaking, arachidonic acid eicosanoids are pro-inflammatory [6,27], while n-3 PUFA and especially their long-chain derivate have anti-inflammatory capacities $[6,28]$, by modifying the cyclooxygenase (COX) and lipoxygenases (LOX) pathways. [6,29]

\section{Omega-3 fatty acids and athletic performance}

Diet supplementation with omega-3 fatty acids is a need for athletes, diets rich in omega- 3 fatty acids (EPA and DHA) being able to have benefic effects on mood, behavior and physical performance.[30,31] Moreover, omega- 3 intake is associated with a number of positive effects on the health status. Omega-3 fatty acids can protect against cardiovascular diseases [8,32] and cardiac arrhythmias [8,33]; they lower triglyceride levels and increase HDL-cholesterol levels, they lower blood pressure, increase oxygen supply to the myocardium during physical exercise and therefore lower the risk for cardiovascular diseases. Moreover, omega-3 fatty acids increase the basal metabolism and the oxidation rate for fatty acids, as well as the production of endogenous antioxidant enzymes (catalase, glutathione peroxidase and superoxide dismutase), they increase insulin sensibility, lower the risk for metabolic syndrome and have platelet anti-aggregation activity. [22]

Both physical exercise and endurance training lead to an increased consumption of fats with favorable effects on the health status.

As numerous studies have shown, regular physical exercise is associated with the prevention of cardiovascular disease, arterial hypertension, obesity, diabetes mellitus, cancer, depression, osteoporosis and premature death. [22,34,35] Regular physical activity lower the cardiovascular 
risk, by lowering triglyceride levels, increasing HDLcholesterol levels and lowering LDL-cholesterol levels. [22]

It was proven that physical activity per se, together with fatty acids intake through diet (representing the main component of the cell membrane) $[22,36]$, can be a moderator of the fatty acids in membranous phospholipids. [22] In this manner Anderson A. et al., [22,37] have proven that 6 weeks of constant low endurance physical exercise led to significant changes in the structure of the fatty acids in muscular phospholipids, with a significant increase in oleic acid and a decrease in the concentrations of arachidonic acid. [22]

Few studies have analyzed the hypolipidemic, antithrombotic and anti-inflammatory effect of omega-3 fatty acids in competitive athletes. On a usual basis athletes go into exhausting routine training sessions, that puts the body under a lot of pressure and effort, especially if is not associated with a satisfactory food intake. [9] The increased intake of omega-3 fatty acidswas correlated with a better lipid profile, as well as with the reduction of oxidative stress levels, and reduction of inflammation through the inhibition of proinflammatory mediators such as leukotriene, prostaglandins and cytokines. [30,38,39]

In a study carried out by Yates et al. in 2009, which included professional football players, it was shown that supplementing the nutrition with omega- 3 fatty acids has significantly and positively influenced the lipid profile (plasmatic levels of EPA and DHA were increased). The same study has proven that this is a good manner of improving modifiable cardiovascular risk factors related to lipid levels in professional football players. [40,41]

Machado P. et al. have researched the effects of omega-3 fatty acids diet supplementation on the plasmatic lipid profile of swimmers in the time span before a competition. In this direction they have used fish oil (containing a total of $950 \mathrm{mg}$ EPA and $500 \mathrm{mg}$ DHA) in the form of capsules, meaning 2.5 $\mathrm{g} /$ day, for 45 days before the competition. The positive result they have obtain showed a decreased blood concentration of VLDL, LDL and total cholesterol levels, results that sustain the hypothesis of a positive influence of omega-3 fatty acids on the dynamics of lipoproteins in the body of professional athletes. [9]
Physical exercise can be associated with a lowering of postprandial blood sugar levels and with the formation of triglyceride rich lipoproteins, most probably through the late increase in activity of the lipoproteinlipase. [42] Furthermore, the supplementation with omega-3 fatty acids from fish oil can reduce postprandial lipid levels by lowering the hepatic synthesis and secretion of lipoproteins. $[42,43]$

Thomas T.R. et al., have studied the interaction between omega-3 fatty acids ( $4 \mathrm{~g} /$ day) and physical exercise (fast walking and/or jogging, 45 minutes/day, 5 days/week, 4 weeks consecutively) proving lower postprandial lipid levels, after a lipid rich meal, and have also shown that training exercises do not interfere and have no supplementary effects with omega-3 fatty acids, on lowering postprandial lipemia; on the other hand the two treatments can together increase HDLcholesterol levels. [42]

In a review, Harris W.S. has shown that 72 placebo controlled studies, in which diets were supplemented with EPA and DHA (1 to $7 \mathrm{~g}$ ) for at least 2 weeks, have proven a decreased plasma triglyceride concentration between 25 and 30\%. $[9,44]$ Roche H.M., has shown that 1 g omega-3 fatty acids supplementation for 12 weeks has significantly decreased pre-prandial triglyceride levels with $21 \% \cdot[9,45]$ Very important is the duration of supplementation, because low doses of omega-3 administered on longer periods of time could have a positive effect on lowering triglyceride level, an effect that is similar with that obtained if higher doses are given for a shorter period of time. [9] As Baker P.V. and Gibbons G.F. have shown, omega-3 fatty acids lower plasma triglyceride levels by reducing endogenous production of VLDL. $[9,46]$ Intense physical exercise increase the production of reactive oxygen species (ROS), with the generation of high doses of superoxide radical in the double lipid layer of the muscular mitochondria. [22,47] Frequently, when an elite athlete goes through a difficult high intensity training, especially with an eccentriccomponent, lesions might appear in the muscular tissue. These lesions initiate an inflammatory process manifested through increased circulating pro-inflammatory cytokine levels. This inflammatory process can generate free oxygen radicals and could lead to lipid peroxidation. 
$[34,48,49]$ If the training is difficult and prolonged an excess of reactive oxygen species (ROS) is produces and this will lead to oxidative stress. $[34,50,51]$ Few researches go into the effects of endurance physical exercises on the redox state and on the systemic inflammatory effect.

Regarding the effects of endurance training on the oxidative stress the results are contradictory. Deminice R. et. al., have shown that lower levels were registered for oxidative stress biomarkers following an active endurance training session. $[34,52]$ On the other hand McAnulty et. al., said that endurance exercises do not have any effects on oxidative stress biomarkers. [34,53] This divergence can probably be explained by the differences in intensity or status in each of the training sessions. [34] Citing McBride et al., the possible mechanism responsible for the production of reactive oxygen species and for the oxidative stress during endurance exercises could be ischemia-reperfusion at the level of active muscles. $[34,54]$

It was proven that omega- 3 fatty acids reduce the oxidative stress by inhibiting lipid peroxidation and having antioxidant effects. [34,56]

FarzanegiP. et al., have studied the effects of diet supplementation with omega- 3 fatty acids $(1200$ $\mathrm{mg}-720 \mathrm{mg}$ EPA and $480 \mathrm{mg}$ DHA) daily, for 4 weeks, in professional elite karate fighters, that had taken part in an intense training program $(3$ days a week, for 1 month). They have analyzed the oxidative stress index (malondialdehide), the antioxidative index (superoxide dismutase) and lipid profile (cholesterol and triglyceride) and have noticed that supplementation with omega-3 fatty acids has determined an increase in serum concentration of antioxidant biomarkers and a decrease in lipid concentration during rest periods in not trained athletes, but was not sufficient for lowering the oxidative stress induced by exercise. [50]

Atashak S. et al., have proven that omega-3 fatty acids supplementation ( $3000 \mathrm{mg} /$ day for 7 days) in young athletes, handball players, before the beginning of an endurance training, especially when including an eccentric component, can reduce postexercise oxidative stress, by attenuating the increased plasma levels for malondialdehide (MDA). [34]
Possible mechanisms through which omega- 3 fatty acids reduce oxidative stress could be the fact that they are included in lipoproteins and lipid complexes of the membrane, that could make the double bonds less available for free radical denaturation, or through increasing catalase levels, an antioxidant enzyme based on the peroxisome. $[34,57,58]$ It was noticed in the case of a professional athlete that goes through high intensity endurance training (difficult training or taking part in a competition) microtraumas can be produced, with inflammation or pain. [8,34,59] Research carried out by Atashak S. et al., has shown that young handball players, after active endurance exercises, present increased values for muscular cell lesion indices, mainly increased creatinkinase (CK) and lactate dehydrogenase (LDH). At the same time, they have noticed lower CK values (CK produced by endurance exercises) after the administration of omega-3 fatty acids. [34]

Similarly, Tartibian B. et al. showed that at untrained men,who carried out a program of physical exercise and consumed omega-3 fatty acids, was manifested, compared to placebo, a significant trend of reduction in serum $\mathrm{CK}$ and LDH, at different intervals of time, after resistance exercise. [29,34]

Acute intense exercise can produce a significant increase in pro-inflammatory biomarkers in the blood. [34,60] Post-exercise inflammation in athletes can be caused by mechanical stress, local ischemia and/or generation of free radicals in the active skeletal muscle. $[34,61]$

Numerous studies and clinical trials have proven the efficacy of omega- 3 fatty acids in the prevention and treatment of inflammation, because of the fact that they are precursors for prostaglandins (e.g. PG $\left.E_{3}\right)$ that reduce the inflammation and the blood flow. $[8,62]$ Moreover, they reduce thromboxane $A_{2}$ production (that is a platelet aggregator and vasoconstrictor) and the formation of leukotriene $\mathrm{B}_{4}$ (inductor of inflammation). Nevertheless, few researchers have investigated the effects omega-3 supplements on the inflammatory response determined by physical exercise. Tartibian et al., have shown that omega-3 fatty acids diet supplementation attenuates the inflammatory response that appears after excessive physical exercise in untrained men. [29,34] Moreover, Jouris 
$\mathrm{KB}$ et al., have proven attenuation in inflammatory response during physical exercise in healthy adults, during the post-workout times, after supplementing their diets with omega-3 fatty acids. The same authors have researched the effects of short term omega-3 (3000 $\mathrm{mg} /$ day DHA/EPA) supplementation (1 week) on localized inflammation after excessive arm twisting exercises in young healthy adults. As inflammation markers they measured by using non-invasive methods, the muscle soreness, arm swelling (by measuring the arm circumference and volume) and local cutaneous temperature. [8] The results of this study have shown that omega-3 fatty acids supplementation lowers the values of muscle soreness after eccentric resistance exercise, this being a subjective measurement. This effect could prove beneficial to athletes that go through intensive training sessions, and that often lead to delayed onset muscle soreness (DOMS), after the exercise. The authors consider that it is possible for omega-3 fatty acids supplementation to lower delayed onset muscle sorenessthat appears even after excessive low intensity training, as for example in running a marathon. Moreover, it was proven that the subjects involved in the study were capable of more intense and more difficult exercise after supplementing the omega-3 fatty acid intake, most probably because of an increased muscular force and/or because of the reduction of muscle fatigue. The fact that its benefic effects appeared after just 72 hours from the beginning of the new diet, it means that this could be started 7 days before the intense physical activity that could cause pain (for example running a marathon or a period of intensifying the routine training etc.) The possible implications of reducing post-training inflammation could be the reduction of pain, together with shorter recovery periods after the exercise. [8] Muscle pain, another manifestation of inflammation, can appear both in athletes and in healthy adults. In 2014 , Lembke P. et al. have proven that a $2.7 \mathrm{~g} /$ day omega-3 fatty acids supplementation, 30 days prior to an intense eccentric exercise can lead to increased levels of omega-3 fatty acids in healthy adults. The tissue levels of omega- 3 is called omega 3 index (N3 index), and its values between 0 and 12 express the EPA and DHA quantities present in the lipid fraction of tissue cell membranes. [30,63] In addition to this, they have shown reduced levels of pain, for delayed onset post-exercise muscle sorenessin individuals with an N3 index over 4, at 72 and 96 hours after the exercise. [30] According to these authors, increased tissue levels of omega-3 have a protective effect on muscle cells during the exercise; they can act by reducing inflammatory response and afterwards by reducing DOMS. DOMS is a type of pain usually caused by a new and unusual exercise, as for example an exercise with excessive muscular action, where a muscle generates tension in order to control its lengthening rate. [30,64] In general, this type of pain appears 24-48 hours after an exercise and can be associated with swelling, sensitivity, and muscular discomfort, both in healthy adults and in trained athletes, and can last for up to a week after a difficult exercise, being also able to influence athletic performance. $[30,65]$

Clarkson P.M. mentions that the probable pathophysiological mechanism for pain could be inflammation and muscle lesions affecting the myofibrils, the sarcolemma and the sarcoplasmic reticulum. [30,66]

One of the most important links between omega-3 fatty acids and inflammation is the effect unsaturated fatty acids have on eicosanoids, the main mediators of inflammation. As Samuelsson B. has shown, eicosanoids generated by the arachidonic acid are mainly involved in the modulation of the inflammatory response. [30,67] The increased intake of omega-3 fatty acids (EPA and DHA) leads to increased levels inside the inflammatory cells, resulting in decreased production of various eicosanoids (thromboxane, leukotriene, and prostaglandins). [30,68] After Lembke P. et al, the fact that persons with high N3 levels after omega-3 supplementation manifest lower levels of delayed onset muscle soreness, at 72 and 96 hours post-exercise, can be explained by the increased concentrations of polyunsaturated fatty acids in the cell membranes of muscle cells, that leads to better cell elasticity and therefore to a reduced degree for the muscular lesions that might appear during exercise. [30]

In regard to the effects that omega- 3 supplements have on the pulmonary function in healthy adults, the studies have shown that there is no link between omega-3 intake and the pulmonary 
function, although a lower prevalence for pulmonary diseases was observed in Eskimos that have a rich omega-3 fatty acids diet. $[29,69]$ There are only few studies regarding the effects omega- 3 fatty acids on pulmonary function variables during physical activity. A series of epidemiological studies have shown that in general, athletes that go into prolonged and complex exercise sessions and/or intensive and very challenging trainings, present a higher risk for upper respiratory tract infections during the training period and 1-2 weeks afterwards, and that the infection could also be associated with pulmonary dysfunction. $[29,70]$ The effect of omega-3 fatty acids diet supplementation on the pulmonary function of young wrestlers during an intense training was for the first time researched by Tartibian B. et al in 2008. [29] They have noticed that a $1000 \mathrm{mg} /$ day omega-3 intake for 12 weeks of intensive wrestling training had a significantly positive effect on certain pulmonary parameters such as FEV1 (Forced expiratory volume in 1 second), FVC (Forced vital capacity), and VC (Vital capacity), but did not significantly change the values of FEV1\% (percentage of forced expiratory volume in one second) and FIV1\% (percentage of forced inspiratory volume in one second). These results suggest that omega- 3 intake during intense wrestling training can improve pulmonary function in these athletes, both during, as well as after the exercise. [29] Moreover, the authors supposed that the changes that appeared in certain pulmonary volumes and pulmonary capacity in the young wrestlers could determine their training adaption ability, as well as improve their pulmonary circulatory system, increase oxygen saturation, improve alveolar ventilation and the partial pressure for oxygen and help wrestlers stay focused. Some authors state that improving the pulmonary function could be thanks to the antiinflammatory effects of omega-3 fatty acids. [29]

It was shown that taking part in high intensity training programs, as for example wrestling, induces the so called exercise-induced bronchoconstriction. This manifests through a transient narrowing of the airways, during or after exercise, resulting in decreased pulmonary function consecutive the exercise. In elite athletes this type of bronchoconstriction prevails, with its symptoms similar to asthmas. The relatively high incidence of the exercise-induced bronchoconstriction in elite athletes could have its roots in exercise hyperventilation, prolonged exposure to allergens and irritants, or excessive exposure to cold and dry air. It probably involves more than one mechanism. It was suggested that transient dehydration of the airways activated the release of inflammation mediators from the airway cells (histamine, neuropeptides, metabolites of the arachidonic acid, leukotriene, and prostaglandins) resulting in the contraction of the bronchial smooth muscle. [22] In addition, to this bronchoconstriction can also contribute repetitive high intensity exercises, by the release of proinflammatory cytokines. [22,71]

Mickleborough T.D. et al., have investigated the effects of fish oil supplementation on the severity of exercise-induced bronchoconstriction in performance athletes and they have found that omega-3 supplemented diets intensify the pulmonary function in the lot that had received the omega-3 supplementation in comparison to those that did not receive omega- 3 fatty acids or had received a placebo. $[29,72]$.

This protective effect of suppression of exerciseinduced bronchoconstriction in performance athletes is most probably due to the antiinflammatory properties that omega-3 fatty acids (from the fish oil that had been administered) hold [22].

\section{Conclusions}

A balanced intake of omega- 6 and omega- 3 fatty acids is very important for improving overall health and to reduce the risk of some diseases. Omega-3 fatty acids regulate a variety of biological functions, decrease the risk of cardiovascular disease and cardiac arrhythmias, reduce the risk of metabolic syndrome and have antiplatelet effect.

Omega-6, and especially omega-3 fatty acids supplementation, play very important roles throughout the body, contributing to the maintenance and promotion of health. Omega-3 fatty acids intake is a necessity for global health, omega-3 fatty acids rich diets (EPA and DHA) having beneficial effects on the mood, and behavior, as well as on the physical exercise and athletic performance. The beneficial effects of omega-3 fatty acids diet supplementation in athletes are explained by the improvement of the lipid profile, the 
reduction of oxidative stress, inflammation and post-exercise pain, as well as the reduction of exercise-induced bronchoconstriction. In order to obtain beneficial effects on the athletic performance

\section{Reference}

1. Hansen A.E., Wiese H.F., Boelsche A.N., Haggard M.E., et al. (1963). Role of linoleic acid in infant nutrition. Clinical and chemical study of 428 infants fed on milk mixtures varying in kind and amount of fat, Pediatrics 31, 171-192.

2. Candela C.G., López L.M.B, Kohen V.L. (2011). Importance of a balanced omga 6/omega 3 ratio for the maintenance of health. Nutritional recommendations, Nutr. Hosp., 26(2), 323-329.

3. Franzen-Castle L.D., Ritter-Gooder P. (2010). Omega-3 and Omega-6 fatty acids, NebGuide University of NebraskaLincoln Extension, Institute of Agriculture and natural Resources, Issued August, http://extension.unl.edu/publications.

4. Manea C. M., Bulduș C.F., Tache S. (2014). The importance of omega-3 fatty acids in diet, Palestrica of the third millennium - Civilization and Sport, 15(2), 131-133.

5. Calder P.C. (2008). Polyunsaturated fatty acids, inflammatory processes and inflammatory bowel diseases, Molecular Nutrition and Food Research, 52(8), 885-897.

6. Patterson E., Wall R., Fitzgerald G.F., Ross R.P., Stanton C. (2012). Health implications of high dietary omega-6 polyunsaturated fatty acids, Journal of Nutrition and Metabolism Article, ID 539426, doi:10.1155/2012/539426, 1-16; www.hindawi.com/journals/jnme/2012/539426/.

7. Wall R., Ross R.P, Fitzgerald G.F., Stanton C. (2010). Fatty acids from fish: the anti-inflammatory potential of long-chain omega-3 fatty acids, Nutrition Reviews, 68(5), 280-289.

8. Jouris K.B., McDaniel J.L., Weiss E.P. (2011) The effect of omega-3 fatty acid supplementation on the inflammatory response to eccentric strength exercise, Journal of Sports Science and Medicine 10, 432-438;

9. Machado A. P. de Mattos, Ribeiro B.G., Tavares do Carmo M. das Graças (2006). Omega 3 fatty acids-supplementation to competition athletes: impact on the biochemical indicators related to the lipid metabolism, Rev. Bras. Med. Esporte, 12(6), 3003e-307e.

10. Schmidt E.B., Skou H.A., Christensen J.H., Dyerberg J. (2000) $N-3$ fatty acids from fish and coronary artery disease: implications for public health, Public Health Nutr., 3(1), 9198.

11. Simopoulos A.P. (2002) The importance of ratio omega6/omega-3 essential fatty acids, Biomed Pharmacother., 56, 365-379.

12. Oliver M.C., Vanessa L., Isabelle A.L. (2011) Why and how meet n-3 PUFA dietary recommendations?, Gastroenterology Research and Practice, http://dx.doi.org/10.1155/2011/364040, 11 pages.

13. Anderson B.M., Ma D.W.L. (2009) Are all n-3 polyunsaturated fatty acids created equal?, Lipids in health and Disease 8, 33, https://lipidworld.biomedcentral.com/articles/10.1186/14 76-511X-8-33. an educational program regarding the consumption of omega- 3 and omega- 6 rich foods is needed.

14. Simopoulos A.P. (2011). Evolutionary aspects of diet: the omega-6/omega-3 ratio and the brain, Molecular Neurobiology, 44(3), 203-215.

15. Granados S., Quiles J.L., Gil A., Ramírez-Tortosa M.C. (2006) Lípidos de la dieta y cáncer, Nutr. Hosp., 21, 44-54.

16. Simopoulos A.P. (2009) Omega-6/omega-3 essential fatty acids: biological effects, World Rev. Nutr. Diet, 99, 1-16.

17. García-Ríos A., Meneses M.E., Pérez-Martínez P., PérezJiménez F. (2009) Omega-3 y enfermedadcardiovascular: másallá de los factores de riesgo, Nutr. Clín. Diet Hosp., 29(1), 4-16.

18. De Lorgeril M., Salen P. (2012) New insights into the health effects of dietary saturated and omega- 6 and omega-3 polyunsaturated fatty acids, BMC Medicine 10, 50, http://www.biomedcentral.com/1741-7015/10/50.

19. deLorgeril M., Salen P. (2008) The Mediterranean diet: rationale and evidence for its benefit, Curr. Atheroscler. Rep., 10, 518-522.

20. deLorgeril M., Salen P. (2011) Mediterranean diet in secondary prevention of CHD, Public Health Nutr., 14, 23332337.

21. Graber R., Sumida C., Nunez E.A. (1994) Fatty acids and cell signal transduction, J. Lipid Mediat., Cell Signal, 9, 91-116.

22. Simopoulos A.P. (2007) Omega-3 fatty acids and athletics, Current Sports Medicine Reports, 6, 230-236.

23. Wang D., Dubois R.N. (2010) Eicosanoids and cancer, Nature Reviews Cancer, 10(3), 181-193.

24. Das U.N. (2006) Essential fatty acids: biochemistry, physiology and pathology, Biotechnology Journal, 1(4), 420439.

25. Benatti P., Peluso G., Nicolai R., Calvani M. (2004) Polyunsaturated fatty acids: biochemical, nutritional and epigenetic properties, Journal of the American College of Nutrition, 23(4), 281-302.

26. Simopoulos A.P. (2002) Omega-3 fatty acids in inflammation and autoimmune diseases, Journal of the American College of Nutrition, 21(6), 495-505.

27. Ricciotti E., Fitzgerald G.A. (2011) Prostaglandins and inflammation, Arteriosclerosis, Thrombosis, and Vascular Biology, 31(5), 986-1000.

28. Tai C.C., Ding S.T. (2010) N-3 polyunsaturated fatty acids regulate lipid metabolism through several inflammation mediators: mechanisms and implications for obesity prevention, Journal of Nutritional Biochemistry, 21(5), 357363.

29. Tartibian B., Maleki B.H., Abbasi A. (2010) The effects of omega-3 supplementation on pulmonary function of young wrestlers during intensive training, Journal of Science and Medicine in Sport ,13, 281-286.

30. Lembke P., Capodice J., Hebert K., Swenson T. (2014) Influence of omega-3 (N3) Index on performance and wellbeing in young adults after heavy eccentric exercise, Journal of Sports Science and Medicine, 13, 151-156. 
31. Poudyal H., Panchal S.K., Diwan V., Brown L. (2011) Omega3 fatty acids and metabolic syndrome: effects and emerging mechanisms of action, Progress in Lipid Research 50, 372387.

32. Lavie C.J., Milani R.V., Mehra M.R., Ventura H.O. (2009) Omega-3 polyunsaturated fatty acids and cardiovascular diseases, Journal of the American College of Cardiology, 54, 585-594.

33. Richardson E.S., Iaizzo P.A., Xiao Y.F. (2011) Electrophysiological mechanisms of the anti-arrhytmic effects of omega-3 fatty acids, Journal of Cardiovascular Translational Research, 4, 42-52.

34. Atashak S., Sharafi H., Azarbayjani M.A., et al. (2013) Effect of omega-3 supplementation on the blood levels of oxidative stress, muscle damage and inflammation markers after acute resistance exercise in young athletes, Kinesiology, 45(1), 2229.

35. Belviran M., Gökber H. (2006) Acute exercise induced oxidative stress and antioxidant changes, European Journal of General Medicine, 3, 126-131.

36. McMurchie E.J., Margetts B.M., Beilin L.J. et al. (1996) Dietary-induced changes in the fatty acid composition of human cheek cell phospholipids: correlation with changes in the dietary polyunsaturated/saturated fat ratio, Am. J. Clin. Nutr., 39, 975-980.

37. Andersson A., Sjödin A., Olsson R., Vessby B. (1998) Effects of physical exercise on phospholipid fatty acid composition in skeletal muscle, Am. J. Physiol. Endocrinol. Metab., 274, E432-E438.

38. Gopinath B., Buyken A.E., Flood V.M., et al. (2011) Consumption of polyunsaturated fatty acids, fish, and nuts and risk of inflammatory disease mortality, American Journal of Clinical Nutrition, 93, 1073-1079.

39. Huang J., Frohlich J., Ignaszewski A.P. (2011) The impact of dietary changes and dietary supplements in lipid profile, Canadian Journal of cardiology, 27, 488-505.

40. Sinnott R.A., Maddela R.L., Bae S., Best T. (2013) The effect of dietary supplements on the quality of life of retired professional football players, Global Journal of Health Science, 5(2), 13-26.

41. Yates A., Norwig J., Maroon J.C., Bost J., et al. (2009) Evaluation of lipid profiles and the use of omega-3 essential fatty acid in professional football players, Sports Health 1(1), 21-30.

42. Thomas T.R., Ying L., Melissa A.L., Rector R.S. (2007) Interaction of exercise training and $n-3$ fatty acid supplementation on postprandial lipemia, Appl. Physiol. Nutr. Metab., 32, 473-480.

43. Park Y., Harris W.S. (2003) Omega-3 fatty acid supplementation accelerates chylomicron triglyceride clearance, J. Lipid Res., 44, 455-463.

44. Harris W.S. (1996) N3 fatty acids and lipoproteins: comparison of results from human and animal studies, Lipids, $31,243-252$.

45. Roche H.M., Gibney M.J. (1999) Long-chain n-3 polyunsaturated fatty acids and triacylglycerol metabolism in postprandial state, Lipids, 34, S259-S265.

46. Baker P.W., Gibbons G.F. (2000) Effect of dietary fish oil on the sensitivity of hepatic lipid metabolism to regulation by insulin, J. Lipid Res., 41(5), 719-726.

47. Karlsson J. (1997) Exercise, muscle metabolism and the antioxidant defense, World Rev. Nutr. Diet, 82, 81-100.
48. Güzel N.V., Hazar S., Erbas D. (2007) Effects of different resistance exercise protocols on nitric oxide, lipid peroxidation and creatine kinase activity in sedentary males, Journal of Sports Science and Medicine, 6, 417-422.

49. Clarkson P.A., Thomson H.D. (2000) Antioxidants: what role do they play in physical activity and health?, American Journal of Clinical Nutrition, 72, 637-646.

50. Farzanegi P., Sefid NMR, Habibian M., Jafari H. (2012) The effects of omega-3 on oxidative stress in elite karate athletes, J. Mazand Univ. Med. Sci., 22(91), 70-78.

51. Fatouros I.G., Jamurtas A.Z., Viliotou V., et al. (2004) Oxidative stress responses in older men during endurance training and detraining, Medicine and Science in Sports and Exercise, 36, 2065-2072.

52. Deminice R., Sicchieri T., Payão P.O, Jardão A.A. (2010) Blood ans salivary oxidative stress biomarkers following an acute session of resistance exercise in humans, International Journal of Sports Medicine, 32, 599-603.

53. McAnulty S., McAnulty L., Nieman D., et al. (2005) Effect of resistance exercise and carbohydrate ingestion on oxidative stress, Free Radical Research, 39, 1219-1224.

54. McBride J.M., Kreamer W.Y. (1999) Free radicals, exercise, and antioxidants, Journal of Strength and Conditioning Research, 13, 175-183.

55. McBride J.M., Kraemer W.Y., Triplett-McBride T., Sebasianelli W. (1998) Effect of resistance exercise on free radical production, Medicine and Science in Sports and Exercise, 30, 67-72.

56. Taccone-Gallucci M., Manca-di-Villahermosa S., Battistini L., et al. (2006) N-3 PUFAs reduce oxidative stress in ESRD patients on maintenance $H D$ by inhibiting 5-lipoxygenase activity, Kidney International, 69, 1450-1454.

57. Mori T.A., Dunstan D.W., Burke V., Croft K.D., et al. (1999) Effect of dietary fish and exercise training on urinary F2isoprostane excretion in non-insulin-dependent diabetic patients, Metabolism, 148, 402-408.

58. Masters C. (1996) Omega-3 fatty acids and the peroxisome, Molecular and Cellular Biochemistry, 165, 83-93.

59. Roth S.M., Martel G.H., Ivey F.M., et al. (2000) High-volume, heavy-resistance strength training and muscle damage in young and older women, Journal of Applied Physiology, 88, 1112-1118.

60. Petersen A.M., Pedersen B.K. (2005) The anti-inflammatory effect of exercise, Journal of Applied Physiology, 98, 11541162.

61. Ghiasvand R., Djalali M., Djazayery S.A., et al. (2010) Effect of eicosapentaenoic acid (EPA) and vitamin $E$ on the blood levels of inflammatory markers, antioxidant enzymes, and lipid peroxidation in Iranian basketball players, Iranian Journal of Public Health, 39, 15-21.

62. Calder P.C. (2006) N-3 polyunsaturated fatty acids, inflammation, and inflammatory disease, American Journal of Clinical Nutrition, 83, 1505S-1519S.

63. von Schacky C. (2010) Omega-3 Index and cardiovascular disease prevention: principle and rationale, Lipid Technology 22(7), 151-174.

64. Wessel J., Wan A. (1994) Effect of stretching on the intensity of delayed-onset muscle soreness, Clinical Journal of Sport Medicine, 4, 82-87.

65. Jamtyedt G., Herbert R.D., Flottorp S., et al. (2010) $A$ pragmatic randomized trial of stretching before and after 
physical activity to prevent injury and soreness, British Journal of Sports Medicine, 44, 1002-1009.

66. Clarkson P.M., Sayers S.P. (1999) Etiology of exerciseinduced muscle damage, Canadian Journal of Applied Physiology, 24, 234-248.

67. Samuelsson B. (1991) Arachidonic acid metabolism: role in inflammation, Rheumatology, 50(1), 3-6.

68. Healy D.A., Wallace F.A., Miles E.A., Calder P.C., Newsholme P. (2000) The effect of low to moderate amounts of dietary fish oil on neutrophil lipid composition and function, Lipids $35,763-768$.

69. Schwartz J. (2000) Role of polyunsaturated fatty acids in lung disease, Am. J. Clin. Nutr., 393s-396s.

70. David C.N. (2007) Marathon training and immune function, Sports Med., 37(4-5), 1.

71. Davis M.S., Freed A.N. (1999) Repetitive hyperpnoea causes peripheral airway obstruction and eosiniphilia, Eur. Respir. J., 14, 57-62.

72. Mickleborough T.D., Murray R.L., Ionescu A.A., Lindley M.R. (2003) Fish oil supplementation reduces severity of exerciseinduced bronchoconstriction in elite athletes, Am. J. Respire. Crit. Care Med., 168, 1181-1189. 